\title{
Shell Roof of Tall Buildings in Earthquake Zones
}

\author{
Mohammed Salem Al-Ansari, Muhammad Shekaib Afzal* \\ Department of Civil and Architectural Engineering, Qatar University, Doha, Qatar \\ Email: *shekaib@qu.edu.qa
}

How to cite this paper: Al-Ansari, M.S. and Afzal, M.S. (2019) Shell Roof of Tall Buildings in Earthquake Zones. Open Journal of Earthquake Research, 8, 223-238. https://doi.org/10.4236/ojer.2019.84013

Received: August 24, 2019

Accepted: October 14, 2019

Published: October 17, 2019

Copyright (c) 2019 by author(s) and Scientific Research Publishing Inc. This work is licensed under the Creative Commons Attribution International License (CC BY 4.0).

http://creativecommons.org/licenses/by/4.0/

\begin{abstract}
This paper studies and analyzes tall buildings with shell and flat roof responses designed for gravity and earthquake loads in different zones having different soil profiles. These tall buildings having two different heights and different configurations are simulated with different load combinations. The responses of the simulated structural models with flat and shell roofs are studied and analyzed. These responses draw recommendations and guidelines for preliminary design of structurally efficient and reliable tall buildings with shell roof in earthquake zones. Five different earthquake zone factors (Z1 $\mathrm{Z5}$ ) along with the five different soil profiles (S1 - S5) are selected in this study. The non-linear dynamic response of buildings was obtained using three simulated models of buildings; square/rectangular, circular, and tube-shaped building. Total of 12 building models, four under each category, are analyzed using the finite element software (STAAD pro) subjected to the gravity as well as earthquake loading defined by UBC and IBC codes. Each building model is analyzed with two different story heights; which are 120 meters for 30 stories and 72 meters for 18 stories respectively. Horizontal and vertical displacement comparison is made among the flat roof and shell roof building for 32 and 18 stories building satisfying the ACI code of design requirement and drift index of 1/500 (0.002). The results showed that the drift index value for all the studied buildings is close to 0.002 . All the maximum horizontal and vertical deflections occur under the earthquake zone-5 (0.40 gravitational acceleration) with soil profile-5 (Soft soil). The shell roof slab with less thickness than the flat roof slab did satisfy the horizontal and vertical deflection limits, therefore, it is more economical than the flat roof slab.
\end{abstract}

\section{Keywords}

Shell Roof, Earthquake Loads, Flat Roof, Building Drift, Structural and Soil Parameters 


\section{Introduction}

The lateral displacement or drift of structural systems during an earthquake has an important impact on their potential failure. The probability of failure of structures is therefore reduced by limiting their lateral displacements or drifts. Drift limitations are currently imposed by seismic design codes, such as Uniform building Code (UBC) [1] and International Building Code (IBC) [2], to design safe buildings satisfying the ACI code of design requirement [3]. Previous research studies focused on the different reinforced concrete tall buildings having flat roof subjected to earthquake loading. Khobragade, N. D., and A. Nikhade [4] studied the effect of different seismic zones on the performance of $\mathrm{G}+10$ multi-story flat roof RC building. Three dimensional (3D) models of building were developed to analyze and compare the effect of seismic forces on multistory building by commercially available computer software (STADD Pro). Naidu, M. and Bhole, S. D. [5] studied on the foundation of reinforced concrete building for 5,10 , and 15 stories under the various seismic zones of Indian subcontinent. Imam [6] investigated the deflection characteristics of mat foundation for structural and soil parameters using the finite element software (SAFE). Al-Ansari and Ahmed S. [7] presented a Drift Design Structural Model (DDSM) for the design optimization of high-rise buildings in seismic zones. The structural model was formulated as generalized single degree of freedom system subjected to equivalent static seismic loadings. Seven high-rise building models were analyzed to validate the proposed model.

Al-Ansari [8] in another study developed a reliability index approach to access the reliability of tall buildings subjected to earthquake loading. Square, circular and tube-shaped building models with 18 and 30 stories were simulated using the STAAD pro software. The result showed that reliability index model is flexible and can be used for all types of buildings having all local and international design codes. Al-Ansari [9] also presented a numerical method using a simple closed-form equation to compute the building response under earthquake load. The results obtained were in close agreement with the finite element software (STAAD pro.). Also, this closed-form equation can predict the top drift of some buildings under earthquake response.

The acceptable range for the drift index of conventional structures lies between the values of 0.002 and 0.005 (that is approximately $1 / 500$ to $1 / 200$ ) [8]. The ratio of lateral deflection of a building to its height is known as drift index [10]. Excessive lateral displacements or drifts can cause failure in both structural and non-structural elements. Therefore, drifts at the initial structural design stages must not exceed the specified index limits [11] [12].

This paper studies and analyzes tall buildings with shell roof responses designed for gravity and seismic loads in different zones having different soil profiles. These tall buildings having different heights and with different configurations are simulated with different load combinations. Five different zone factors (Z1 - Z5) along with the five different soil profiles (S1 - S5) used in this study are listed in Table 1. 
Table 1. Soil profile and seismic factors.

\begin{tabular}{ccc}
\hline Sr. No & Soil Type (S) & Seismic Factors (Z) \\
\hline 1 & Hard Rock (S1) & 0.075 gravitational acceleration $(\mathrm{Z} 1)$ \\
2 & Rock (S2) & 0.150 gravitational acceleration $(\mathrm{Z} 2)$ \\
3 & Very dense soil and soft rock (S3) & 0.20 gravitational acceleration $(\mathrm{Z3})$ \\
4 & Stiff soil (S4) & 0.30 gravitational acceleration $(\mathrm{Z} 4)$ \\
5 & Soft soil (S5) & 0.40 gravitational acceleration $(\mathrm{Z5})$ \\
\hline
\end{tabular}

The non-linear dynamic response of buildings was obtained using three simulated models of buildings; square/rectangular, circular, and tube with different heights (Figure 1).

Each model building is analyzed using the computer software (STAAD Pro) to find the vertical and horizontal displacements of the flat shaped roof and to compare the results with the dome shaped roof of same model building under the seismic loading conditions having different soil profiles. Each model building is analyzed with two different story heights; which are 120 meters for 30 stories and 72 meters for 18 stories respectively. Table 2 shows the building code specification matrix for the analyzed models.

The Elevation and the plan view for these three selected models; square, circular and tube-shaped buildings with different heights $(120 \mathrm{~m}$ and $72 \mathrm{~m})$ are shown in Figures 2-4 respectively.

\section{Roof Displacement of Stimulated Structural Models}

The twelve different building models as discussed in Table 2 are analyzed by using the finite element software (STAAD pro) subjected to the gravity as well as earthquake loading defined by UBC and IBC. Their responses are obtained under five different zone factors (Z1 - Z5) having five different soil profiles (S1 S5).

Horizontal and vertical displacement comparison is made between the flat roof and shell roof building for 32 and 18 stories building. The detailed results for each shaped building are discussed in this section.

\subsection{Square/Rectangular Building}

This section includes the results of 18 and 30-story square building subjected to gravity and earthquake loading. The buildings, which come under this category, are SRB-S-18, SRB-F-18, SRB-S-30 and SRB-F-30. Table 3 includes the detailed results of horizontal and vertical displacements for shell and flat roof square building.

The maximum horizontal displacement $\left(\Delta_{H(\max )}\right)$ allowed for 18-story building is $\left(\Delta_{H(\max )}=H / 500\right)=72,000 / 500=144 \mathrm{~mm}$ whereas the maximum vertical displacement $\left(\Delta_{V(\max )}\right)$ allowed is $\left(\Delta_{V(\max )}=L / 120\right)=5000 / 120=41.7 \mathrm{~mm}$. Moreover, for the 30 -story building, the maximum vertical displacement will 


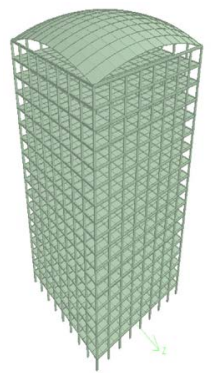

Model -1 (Square/Rect.)

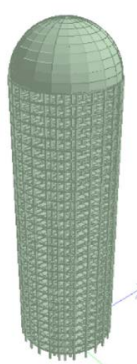

Model -2

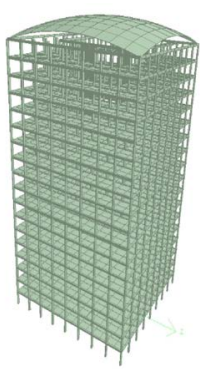

Model -3 (Tube-Shaped)

Figure 1. 3D Structural building models.

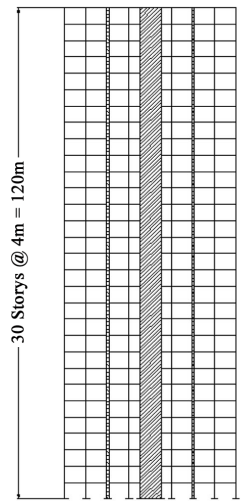

SECTION 1-1 (30 STORY)

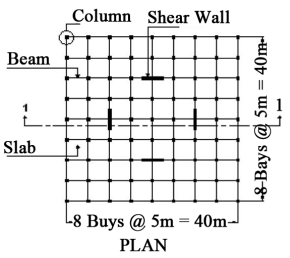

(a)

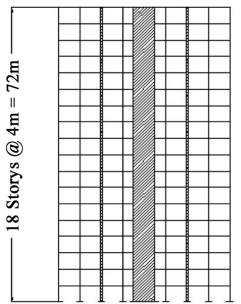
SECTION 1-1 (18 STORY)

1

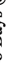

(a)

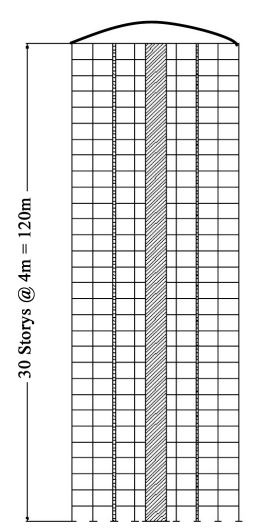

SECTION 1-1 (30 STORY) Column Shear Wall

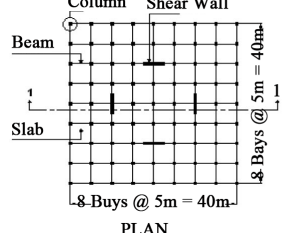

PLAN

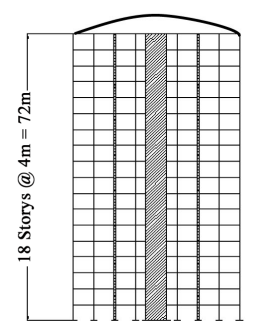

SECTION 1-1 (18 STORY)

Figure 2. Elevation and plan view of square/rec building (30 and 18 stories). (a) Flat roof building; (b) Shell roof buildings.

Table 2. Building code specification matrix.

\begin{tabular}{ccc}
\hline Sr. No & Building Code & Building type \\
\hline 1 & SRB-F-30 & Square/Rec Building with Flat Roof (30 stories) \\
2 & SRB-S-30 & Square/Rec Building with Shell Roof (30 stories) \\
3 & CB-F-30 & Circular Building with Flat Roof (30 stories) \\
4 & CB-S-30 & Circular Building with Shell Roof/Dome (30 stories) \\
5 & TB-F-30 & Tube shaped Building with Flat Roof (30 stories) \\
6 & TB-S-30 & Tube shaped Building with Shell Roof (30 stories) \\
7 & SRB-F-18 & Square/Rec Building with Flat Roof (18 stories) \\
8 & SRB-S-18 & Square/Rec Building with Shell Roof (18 stories) \\
9 & CB-F-18 & Circular Building with Flat Roof (18 stories) \\
10 & CB-S-18 & Circular Building with Shell Roof/Dome (18 stories) \\
11 & TB-F-18 & Tube shaped Building with Flat Roof (18 stories) \\
12 & TB-S-18 & Tube shaped Building with Shell Roof (18 stories) \\
\hline
\end{tabular}


Table 3. Square building displacement results.

\begin{tabular}{|c|c|c|c|c|c|c|c|c|c|c|c|c|c|}
\hline \multirow{3}{*}{$\begin{array}{c}\text { EQ } \\
\text { Zone }\end{array}$} & \multirow{3}{*}{$\begin{array}{l}\text { Soil } \\
\text { Type }\end{array}$} & \multicolumn{12}{|c|}{ BUILDING MODEL (Square/Rectangular) } \\
\hline & & \multicolumn{3}{|c|}{ SRB-S-18 } & \multicolumn{3}{|c|}{ SRB-F-18 } & \multicolumn{3}{|c|}{ SRB-S-30 } & \multicolumn{3}{|c|}{ SRB-F-30 } \\
\hline & & $\begin{array}{c}t_{\text {Shell }} \\
(\mathrm{mm})\end{array}$ & $\begin{array}{c}\Delta_{V} \\
(\mathrm{~mm})\end{array}$ & $\begin{array}{c}\Delta_{H} \\
(\mathrm{~mm})\end{array}$ & $\begin{array}{c}t_{\text {Slab }} \\
(\mathrm{mm})\end{array}$ & $\begin{array}{c}\Delta_{V} \\
(\mathrm{~mm})\end{array}$ & $\begin{array}{c}\Delta_{H} \\
(\mathrm{~mm})\end{array}$ & $\begin{array}{c}t_{\text {Shell }} \\
(\mathrm{mm})\end{array}$ & $\begin{array}{c}\Delta V \\
(\mathrm{~mm})\end{array}$ & $\begin{array}{c}\Delta_{H} \\
(\mathrm{~mm})\end{array}$ & $\begin{array}{c}t_{\text {Slab }} \\
(\mathrm{mm})\end{array}$ & $\begin{array}{c}\Delta_{V} \\
(\mathrm{~mm})\end{array}$ & $\begin{array}{c}\Delta_{H} \\
(\mathrm{~mm})\end{array}$ \\
\hline \multirow{5}{*}{$\begin{array}{c}(1) \\
0.075\end{array}$} & 1 & 120 & -19.83 & 25.65 & 170 & -13.33 & 14.44 & 170 & -19.23 & 27.23 & 170 & -16.78 & 35.94 \\
\hline & 2 & 120 & -19.96 & 30.40 & 170 & -13.42 & 19.18 & 170 & -19.54 & 35.55 & 170 & -17.00 & 47.92 \\
\hline & 3 & 120 & -20.03 & 32.77 & 170 & -13.46 & 21.55 & 170 & -19.70 & 39.71 & 170 & -17.14 & 53.91 \\
\hline & 4 & 120 & -20.22 & 39.90 & 170 & -13.59 & 28.67 & 170 & -20.16 & 52.19 & 170 & -17.56 & 71.87 \\
\hline & 5 & 120 & -20.68 & 56.53 & 170 & -13.89 & 45.31 & 150 & -20.57 & 80.72 & 170 & -18.92 & 113.80 \\
\hline \multirow{5}{*}{$\begin{array}{c}(2) \\
0.15\end{array}$} & 1 & 120 & -20.22 & 39.90 & 170 & -13.59 & 28.67 & 170 & -20.16 & 52.19 & 170 & -17.56 & 71.87 \\
\hline & 2 & 120 & -20.42 & 47.03 & 170 & -13.71 & 35.80 & 150 & -19.96 & 64.15 & 170 & -18.04 & 89.84 \\
\hline & 3 & 120 & -20.61 & 54.15 & 170 & -13.84 & 42.93 & 150 & -20.42 & 76.58 & 170 & -18.70 & 107.81 \\
\hline & 4 & 120 & -20.87 & 63.66 & 170 & -14.01 & 52.44 & 120 & -17.98 & 89.33 & 170 & -19.58 & 131.76 \\
\hline & 5 & 120 & -21.41 & 83.32 & 170 & -14.35 & 71.47 & 120 & -19.03 & 121.08 & 150 & -20.09 & 178.27 \\
\hline \multirow{5}{*}{$\begin{array}{l}(3) \\
0.2\end{array}$} & 1 & 120 & -20.48 & 49.40 & 170 & -13.76 & 38.17 & 170 & -18.97 & 67.15 & 170 & -18.26 & 95.83 \\
\hline & 2 & 120 & -20.74 & 58.91 & 170 & -13.93 & 47.68 & 170 & -19.52 & 83.20 & 170 & -19.14 & 119.79 \\
\hline & 3 & 120 & -21.01 & 68.41 & 170 & -14.09 & 57.19 & 170 & -20.06 & 99.25 & 170 & -20.03 & 143.74 \\
\hline & 4 & 120 & -21.27 & 77.91 & 170 & -14.26 & 66.71 & 170 & -20.62 & 115.30 & 150 & -19.67 & 166.39 \\
\hline & 5 & 120 & -21.97 & 103.47 & 170 & -14.49 & 81.00 & 150 & -20.70 & 138.41 & 120 & -18.92 & 195.70 \\
\hline \multirow{5}{*}{$\begin{array}{l}(4) \\
0.3\end{array}$} & 1 & 120 & -21.01 & 68.41 & 170 & -14.05 & 57.19 & 170 & -20.06 & 99.25 & 170 & -20.03 & 143.74 \\
\hline & 2 & 120 & -21.40 & 82.67 & 170 & -14.35 & 71.47 & 150 & -20.16 & 122.43 & 150 & -20.09 & 178.27 \\
\hline & 3 & 120 & -21.59 & 89.79 & 170 & -14.52 & 78.62 & 150 & -20.56 & 134.42 & 150 & -20.71 & 196.10 \\
\hline & 4 & 120 & -21.79 & 96.92 & 170 & -14.72 & 85.76 & 120 & -19.84 & 144.88 & 120 & -19.31 & 207.21 \\
\hline & 5 & 120 & -22.80 & 132.24 & 170 & -15.37 & 101.03 & 120 & -20.11 & 153.31 & 120 & -19.31 & 207.21 \\
\hline \multirow{5}{*}{$\begin{array}{l}(5) \\
0.4\end{array}$} & 1 & 120 & -21.67 & 92.70 & 170 & -14.60 & 81.53 & 120 & -20.73 & 158.90 & 120 & -18.97 & 196.99 \\
\hline & 2 & 120 & -22.05 & 106.42 & 170 & -15.13 & 95.29 & 120 & -20.36 & 160.75 & 120 & -20.06 & 230.23 \\
\hline & 3 & 120 & -22.05 & 106.42 & 170 & -15.13 & 95.29 & 120 & -20.36 & 160.75 & 120 & -20.06 & 230.23 \\
\hline & 4 & 120 & -22.31 & 115.93 & 170 & -15.53 & 104.82 & 120 & -20.89 & 176.62 & 130 & -20.82 & 233.25 \\
\hline & 5 & 130 & -23.39 & 135.50 & 170 & -15.98 & 115.47 & 120 & -20.84 & 174.92 & 120 & -19.31 & 207.21 \\
\hline
\end{tabular}

remain the same $(41.7 \mathrm{~mm})$ while the maximum allowed horizontal displacement is $\left(\Delta_{H(\max )}=H / 500\right)=120,000 / 500=240 \mathrm{~mm}$.

The Horizontal and vertical displacement for 18 and 30 stories square building (Flat and Shell Roof) are displayed in Figure 5. The highest vertical displacement for 18 story square building occurs in shell roof building (SRB-S-18) under the earthquake zone- 5 having soil profile 5 with a value of $23.39 \mathrm{~mm}$. For the flat shaped roof building, the maximum vertical displacement of $15.98 \mathrm{~mm}$ also appears in the earthquake zone- 5 having a soil profile- 5 . Moreover, the vertical displacement for 30 story square building is almost similar for shell and flat 


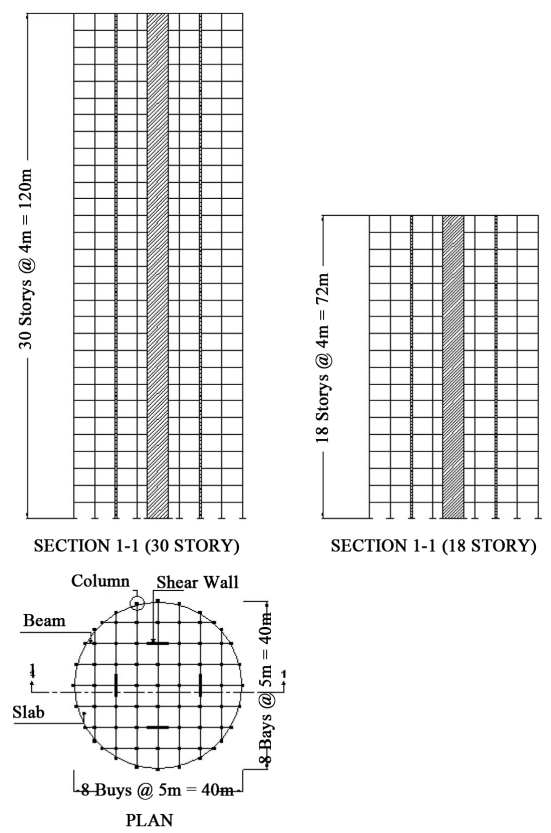

(a)

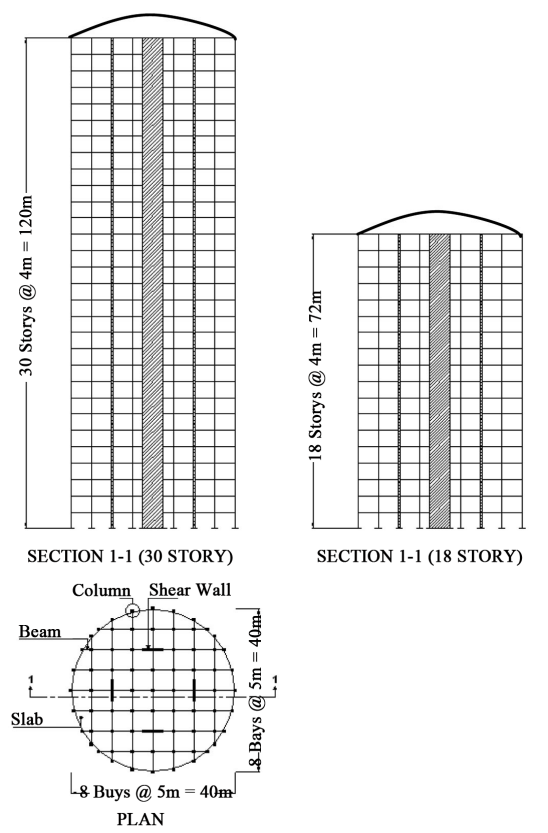

(b)

Figure 3. Elevation and plan view of circular building (30 and 18 stories). (a) Flat roof building; (b) Shell roof buildings.

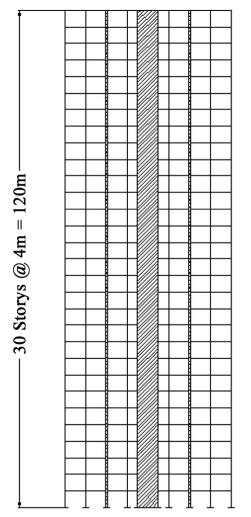

SECTION 1-1 (30 STORY)

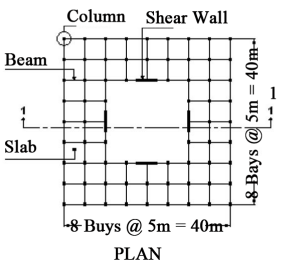

(a)
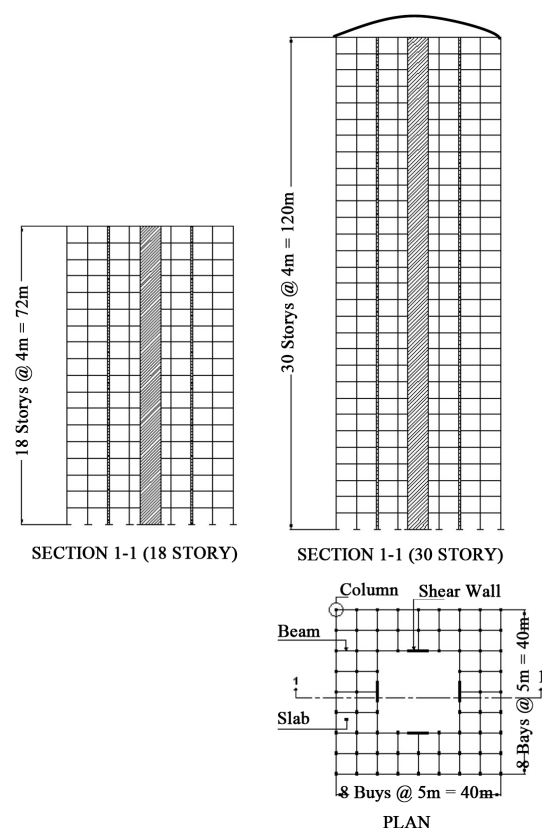

(b)

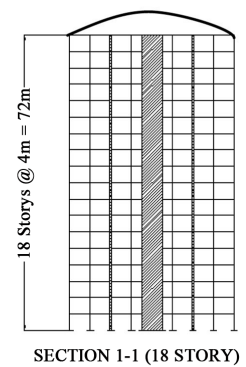

Figure 4. Elevation and plan view of tube-shaped building (30 and 18 stories). (a) Flat roof building; (b) Shell roof buildings.

roof shaped building with the highest value of $20.89 \mathrm{~mm}$ for shell roof building (SRB -S-30) under earthquake zone-5 with a soil profile-4.

The Horizontal displacement of 149.51 is recorded initially for the shell roof (SRB-S-18) building under the earthquake zone-5 with the soil profile-5. This 


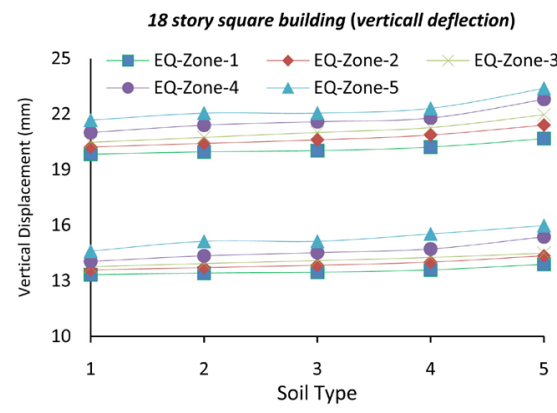

(a)

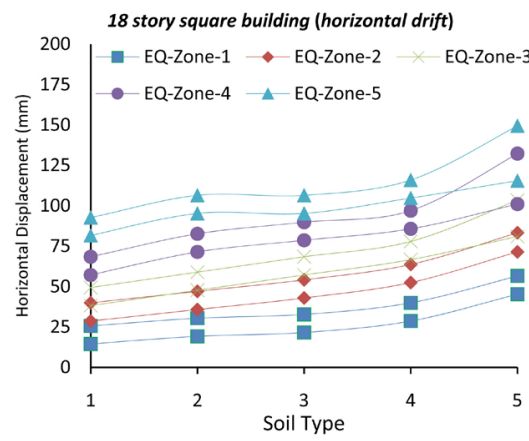

(c)

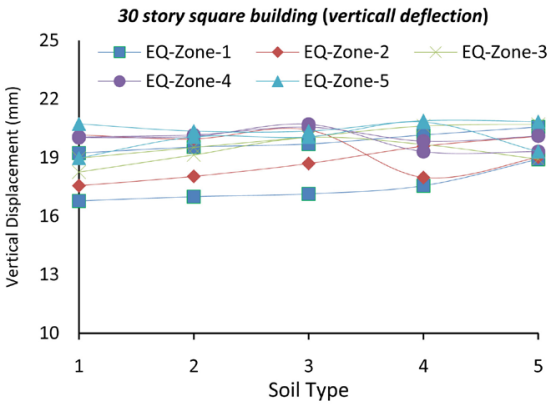

(b)

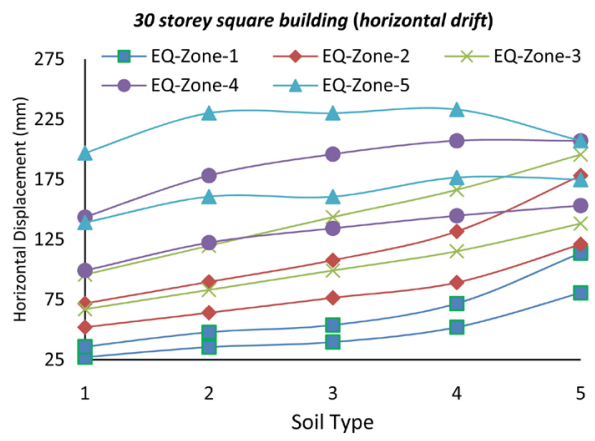

(d)

Figure 5. Vertical and horizontal displacement of square building (30 and 18 stories). (a) Vertical displacement for 18 story square building; (b)Vertical displacement for 30 story square building; (c) Horizontal displacement for 18 story square building; (d)Horizontal displacement for 30 story square building.

value is exceeding the allowable limit $(144 \mathrm{~mm})$ and therefore the shell thickness is increased from $120 \mathrm{~mm}$ to $130 \mathrm{~mm}$, which gives the new horizontal deflection of $135.5 \mathrm{~mm}$. The similar earthquake and soil profile conditions give the highest horizontal drift of $115.47 \mathrm{~mm}$ for the flat roof shaped building (SRB-F-18). Further for the 30 stories square building, the highest horizontal drift occurs in the flat roof building (SRB-F-30) with a value of $253.25 \mathrm{~mm}$ under the earthquake zone 5 with a soil profile- 4 . This value also exceeded the allowable limit (240 $\mathrm{mm}$ ) and thus the roof thickness is increased from $120 \mathrm{~mm}$ to $130 \mathrm{~mm}$, which gives the horizontal deflection of $237 \mathrm{~mm}$.

All the horizontal and vertical displacements tend to increase as the earthquake zone increase from 1 to 5 . The thickness of the shell and flat roof also varies from $120 \mathrm{~mm}$ to $170 \mathrm{~mm}$ from Earthquake zone 1 to 5 in 30 story building, whereas it remains constant of $120 \mathrm{~mm}$ for shell roof and $170 \mathrm{~mm}$ for flat roof of 18 story square building. The vertical and horizontal displacement obtained in all the four above building models is within the range of allowable horizontal and vertical displacement limits.

\subsection{Circular Building}

This section includes the result of 18 and 30-story circular building subjected to gravity and earthquake loading. The buildings, which come under this category, are CB-S-18, CB-F-18, CB-S-30 and CB-F-30. Table 4 includes the detailed 
Table 4. Circular building displacement results.

\begin{tabular}{|c|c|c|c|c|c|c|c|c|c|c|c|c|c|}
\hline \multirow{3}{*}{$\begin{array}{c}\text { EQ } \\
\text { Zone }\end{array}$} & \multirow{3}{*}{$\begin{array}{l}\text { Soil } \\
\text { Type }\end{array}$} & \multicolumn{12}{|c|}{ BUILDING MODEL (Circular) } \\
\hline & & \multicolumn{3}{|c|}{ CB-S-18 } & \multicolumn{3}{|c|}{ CB-F-18 } & \multicolumn{3}{|c|}{$\mathrm{CB}-\mathrm{S}-30$} & \multicolumn{3}{|c|}{ CB-F-30 } \\
\hline & & $\begin{array}{c}t_{\text {Shell }} \\
(\mathrm{mm})\end{array}$ & $\begin{array}{c}\Delta_{V} \\
(\mathrm{~mm})\end{array}$ & $\begin{array}{c}\Delta_{H} \\
(\mathrm{~mm})\end{array}$ & $\begin{array}{c}t_{\text {Slab }} \\
(\mathrm{mm})\end{array}$ & $\begin{array}{c}\Delta_{V} \\
(\mathrm{~mm})\end{array}$ & $\begin{array}{c}\Delta_{H} \\
(\mathrm{~mm})\end{array}$ & $\begin{array}{c}t_{\text {Shell }} \\
(\mathrm{mm})\end{array}$ & $\begin{array}{c}\Delta_{V} \\
(\mathrm{~mm})\end{array}$ & $\begin{array}{c}\Delta_{H} \\
(\mathrm{~mm})\end{array}$ & $\begin{array}{c}t_{\text {Slab }} \\
(\mathrm{mm})\end{array}$ & $\begin{array}{c}\Delta_{V} \\
(\mathrm{~mm})\end{array}$ & $\begin{array}{c}\Delta_{H} \\
(\mathrm{~mm})\end{array}$ \\
\hline \multirow{5}{*}{$\begin{array}{c}(1) \\
0.075\end{array}$} & 1 & 120 & -36.21 & 39.17 & 150 & -8.27 & 8.75 & 120 & -19.62 & 18.78 & 170 & -19.72 & 40.74 \\
\hline & 2 & 120 & -36.19 & 41.62 & 150 & -8.39 & 11.65 & 120 & -19.69 & 24.87 & 170 & -19.75 & 54.31 \\
\hline & 3 & 120 & -36.18 & 42.92 & 150 & -8.46 & 15.56 & 120 & -19.74 & 28.38 & 170 & -19.76 & 61.10 \\
\hline & 4 & 120 & -36.15 & 47.19 & 150 & -8.63 & 21.80 & 120 & -19.88 & 39.09 & 170 & -19.81 & 81.46 \\
\hline & 5 & 120 & -36.08 & 55.11 & 150 & -8.94 & 31.08 & 120 & -20.11 & 58.44 & 120 & -19.48 & 128.32 \\
\hline \multirow{5}{*}{$\begin{array}{c}(2) \\
0.15\end{array}$} & 1 & 120 & -36.15 & 46.53 & 150 & -8.52 & 17.46 & 120 & -19.85 & 37.08 & 170 & -19.81 & 81.46 \\
\hline & 2 & 120 & -29.22 & 50.20 & 150 & -8.51 & 21.81 & 120 & -19.96 & 46.23 & 170 & -20.68 & 101.82 \\
\hline & 3 & 120 & -36.09 & 53.88 & 150 & -8.90 & 29.88 & 120 & -20.07 & 55.41 & 150 & -20.66 & 122.76 \\
\hline & 4 & 120 & -36.06 & 59.16 & 150 & -9.18 & 38.24 & 120 & -20.25 & 69.15 & 120 & -20.31 & 148.58 \\
\hline & 5 & 120 & -35.94 & 74.55 & 150 & -10.23 & 59.72 & 120 & -20.73 & 107.79 & 120 & -22.51 & 202.60 \\
\hline \multirow{5}{*}{$\begin{array}{l}(3) \\
0.2\end{array}$} & 1 & 120 & -36.11 & 51.43 & 150 & -8.69 & 23.26 & 120 & -20.00 & 49.29 & 150 & -20.07 & 109.12 \\
\hline & 2 & 120 & -36.08 & 56.34 & 150 & -8.87 & 29.06 & 120 & -20.15 & 61.5 & 120 & -19.76 & 135.07 \\
\hline & 3 & 120 & -36.03 & 61.24 & 150 & -9.18 & 38.24 & 120 & -20.30 & 73.71 & 120 & -20.86 & 162.08 \\
\hline & 4 & 120 & -36.00 & 66.15 & 150 & -9.63 & 47.78 & 120 & -20.46 & 86.34 & 120 & -21.96 & 189.09 \\
\hline & 5 & 120 & -35.84 & 90.48 & 150 & -11.60 & 76.43 & 120 & -21.10 & 137.85 & 120 & -23.60 & 229.62 \\
\hline \multirow{5}{*}{$\begin{array}{l}(4) \\
0.3\end{array}$} & 1 & 120 & -36.03 & 61.24 & 150 & -9.07 & 34.87 & 120 & -20.30 & 73.71 & 120 & -20.86 & 162.08 \\
\hline & 2 & 120 & -35.98 & 68.60 & 150 & -9.41 & 43.57 & 120 & -20.53 & 92.04 & 120 & -22.52 & 202.60 \\
\hline & 3 & 120 & -35.95 & 72.28 & 150 & -9.93 & 53.75 & 120 & -20.65 & 101.19 & 120 & -23.32 & 222.86 \\
\hline & 4 & 120 & -35.91 & 77.97 & 150 & -10.46 & 64.50 & 120 & -20.83 & 116.37 & 150 & -24.14 & 224.12 \\
\hline & 5 & 120 & -35.71 & 118.75 & 150 & -12.26 & 100.31 & 120 & -21.64 & 180.78 & 150 & -24.14 & 228.12 \\
\hline \multirow{5}{*}{$\begin{array}{l}(5) \\
0.4\end{array}$} & 1 & 120 & -35.94 & 73.78 & 150 & -9.72 & 49.70 & 120 & -20.70 & 104.91 & 150 & -23.24 & 212.52 \\
\hline & 2 & 120 & -35.89 & 81.12 & 150 & -10.14 & 58.08 & 120 & -20.92 & 122.55 & 150 & -24.75 & 232.41 \\
\hline & 3 & 120 & -35.89 & 81.12 & 150 & -10.59 & 66.88 & 120 & -20.92 & 122.52 & 150 & -24.75 & 240.43 \\
\hline & 4 & 120 & -35.83 & 90.48 & 150 & -11.06 & 76.43 & 120 & -21.10 & 137.85 & 160 & -25.80 & 238.20 \\
\hline & 5 & 120 & -35.63 & 135.72 & 150 & -12.98 & 114.63 & 120 & -21.96 & 206.52 & 160 & -24.44 & 236.21 \\
\hline
\end{tabular}

results of horizontal and vertical displacements for shell and flat roof circular building.

For circular shaped 18 story building, the vertical displacement values for flat and shell roof building remained constant under earthquake zones 1 to 5 . The highest vertical displacement $(36.21 \mathrm{~mm})$ for the shell roof building (CB-S-18) occurs at earthquake zone-1 with a soil profile level-1 whereas the highest vertical displacement $(12.98 \mathrm{~mm})$ for the flat roof (CB-F-18) appears under earthquake zone-5 having soil profile level-5. Moreover, the vertical displacement for the 30 stories circular building lies between $19 \mathrm{~mm}$ to $25 \mathrm{~mm}$ with a highest value of $24.44 \mathrm{~mm}$ for flat shaped circular building (CB-F-30). The vertical displacement increases as the earthquake zone increases from 1 to zone 5 with the 
increase in the soil profile level 1 to 5 for the flat shaped roof building whereas, it remained almost constant for the circular shaped building in all the earthquake zones. In addition, the thirty stories circular building has less vertical displacement compared to 18 stories and is also under the allowable vertical displacement limit.

The horizontal displacement for 18 story circular building increases with the increase in the earthquake zone 1 to 5 . Circular building with a shell roof has more value for the horizontal displacement compared to the flat roof circular building.

The maximum horizontal displacement $(135.72 \mathrm{~mm})$ appears under the earthquake zone-5 with a soil profile-5. However, for the 30 stories circular building, the shell roof building has much less horizontal displacement compared to flat roof where the maximum horizontal disp. value of $238.20 \mathrm{~mm}$ is recorded with slab thickness of $160 \mathrm{~mm}$ under the earthquake zone 5 . In the earthquake zone-5, the horizontal displacement obtained in all soil profiles are exceeding the allowable limit of $240 \mathrm{~mm}$ and therefore the slab thickness needs to be increased accordingly.

The Horizontal and vertical displacement for 18 and 30 stories circular building (Flat and Shell Roof) are displayed in Figure 6. The thickness for the shell roof circular building remained constant $(120 \mathrm{~mm})$ for both 18 and 30 stories building whereas for flat roof building, it is $150 \mathrm{~mm}$ for 18 story and variation of $120 \mathrm{~mm}$ to $170 \mathrm{~mm}$ is recorded for 30-story circular building.

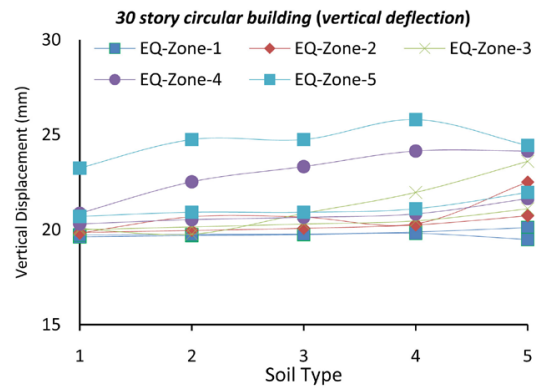

(a)

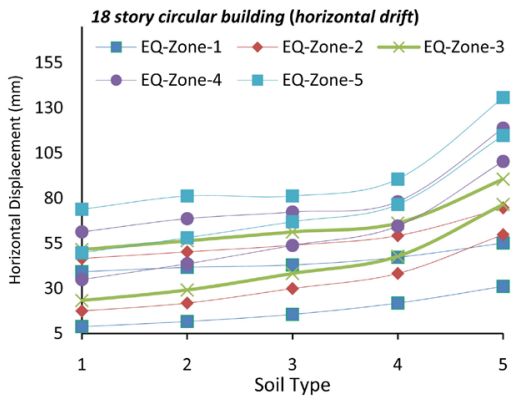

(c)

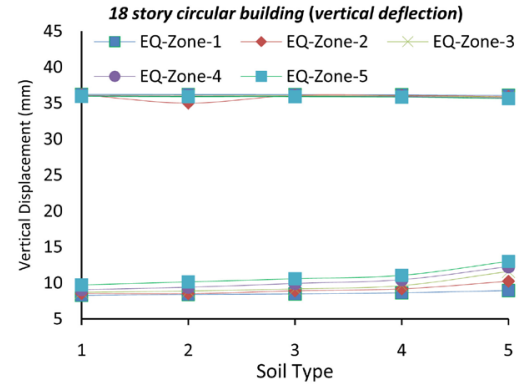

(b)

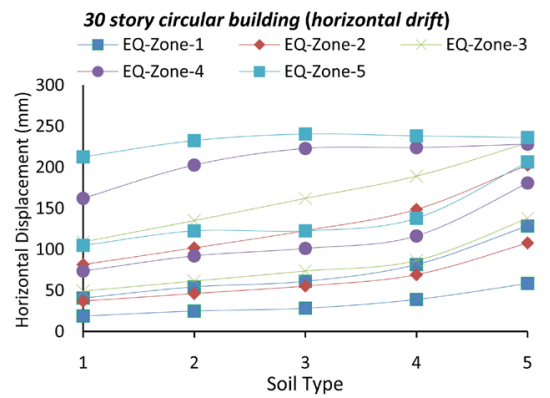

(d)

Figure 6. Vertical and horizontal displacement of circular building (30 and 18 stories). (a) Vertical displacement for 18 story circular building; (b)Vertical displacement for 30 story circular building; (c) Horizontal displacement for 18 story circular building; (d) Horizontal displacement for 30 story circular building. 


\subsection{Tube Shaped Building}

This section includes the result of 18 and 30-story circular building subjected to gravity and earthquake loading. The buildings, which come under this category, are TB-S-18, TB-F-18, TB-S-30 and TB-F-30. Table 5 includes the detailed results of horizontal and vertical displacements for shell and flat roof circular building.

For tube shaped building, the vertical disp. for 18 stories building lies within $15 \mathrm{~mm}$ to $23 \mathrm{~mm}$ for flat and shell roof buildings. Shell roof structure (TB-S-18) has comparatively more vertical disp. compared to flat roof structure for 18 story tube shaped building with a highest vertical disp. value of 22.44 under the earthquake zone- 5 having the soil profile of 4 . The vertical drift for 30 -story tube

Table 5. Tube shaped building displacement results.

\begin{tabular}{|c|c|c|c|c|c|c|c|c|c|c|c|c|c|}
\hline \multirow{3}{*}{$\begin{array}{c}\text { EQ } \\
\text { Zone }\end{array}$} & \multirow{3}{*}{$\begin{array}{c}\text { Soil } \\
\text { Type }\end{array}$} & \multicolumn{12}{|c|}{ BUILDING MODEL (Tube Shaped) } \\
\hline & & \multicolumn{3}{|c|}{ TB-S-18 } & \multicolumn{3}{|c|}{ TB-F-18 } & \multicolumn{3}{|c|}{ TB-S-30 } & \multicolumn{3}{|c|}{ TB-F-30 } \\
\hline & & $\begin{array}{c}t_{\text {Shell }} \\
(\mathrm{mm})\end{array}$ & $\begin{array}{c}\Delta_{V} \\
(\mathrm{~mm})\end{array}$ & $\begin{array}{c}\Delta_{H} \\
(\mathrm{~mm})\end{array}$ & $\begin{array}{c}t_{\text {Slab }} \\
(\mathrm{mm})\end{array}$ & $\begin{array}{c}\Delta_{V} \\
(\mathrm{~mm})\end{array}$ & $\begin{array}{c}\Delta_{H} \\
(\mathrm{~mm})\end{array}$ & $\begin{array}{c}t_{\text {Shell }} \\
(\mathrm{mm})\end{array}$ & $\begin{array}{c}\Delta_{V} \\
(\mathrm{~mm})\end{array}$ & $\begin{array}{c}\Delta_{H} \\
(\mathrm{~mm})\end{array}$ & $\begin{array}{c}t_{\text {Slab }} \\
(\mathrm{mm})\end{array}$ & $\begin{array}{c}\Delta_{V} \\
(\mathrm{~mm})\end{array}$ & $\begin{array}{c}\Delta_{H} \\
(\mathrm{~mm})\end{array}$ \\
\hline \multirow{5}{*}{$\begin{array}{c}(1) \\
0.075\end{array}$} & 1 & 120 & -17.33 & 19.34 & 150 & -15.76 & 17.79 & 120 & -19.52 & 48.031 & 170 & -20.07 & 46.44 \\
\hline & 2 & 120 & -17.60 & 25.33 & 150 & -15.85 & 23.65 & 120 & -20.09 & 63.67 & 170 & -20.32 & 61.90 \\
\hline & 3 & 120 & -17.73 & 28.33 & 150 & -15.89 & 26.60 & 120 & -20.36 & 71.50 & 170 & -20.46 & 69.63 \\
\hline & 4 & 120 & -18.13 & 37.31 & 150 & -16.03 & 35.42 & 120 & -21.22 & 94.96 & 140 & -19.55 & 92.28 \\
\hline & 5 & 120 & -19.08 & 58.28 & 150 & -16.34 & 56.02 & 120 & -23.20 & 149.72 & 130 & -20.51 & 144.42 \\
\hline \multirow{5}{*}{$\begin{array}{c}(2) \\
0.15\end{array}$} & 1 & 120 & -18.13 & 37.31 & 150 & -16.03 & 35.42 & 120 & -21.22 & 94.96 & 120 & -18.60 & 91.07 \\
\hline & 2 & 120 & -18.54 & 46.30 & 150 & -16.16 & 44.25 & 120 & -22.06 & 118.43 & 120 & -19.22 & 113.83 \\
\hline & 3 & 120 & -18.95 & 55.28 & 150 & -16.29 & 53.08 & 120 & -22.92 & 141.90 & 120 & -20.26 & 136.82 \\
\hline & 4 & 120 & -19.48 & 67.26 & 150 & -16.47 & 64.85 & 120 & -24.04 & 173.19 & 120 & -21.25 & 167.21 \\
\hline & 5 & 120 & -20.56 & 91.22 & 150 & -16.83 & 88.39 & 120 & -26.31 & 235.77 & 120 & -23.25 & 227.99 \\
\hline \multirow{5}{*}{$\begin{array}{l}(3) \\
0.2\end{array}$} & 1 & 120 & -18.67 & 49.29 & 150 & -16.20 & 47.19 & 120 & -22.34 & 126.26 & 120 & -19.47 & 121.41 \\
\hline & 2 & 120 & -19.21 & 61.27 & 150 & -16.38 & 58.96 & 120 & -23.47 & 157.55 & 120 & -20.42 & 151.75 \\
\hline & 3 & 120 & -19.75 & 73.25 & 150 & -16.65 & 70.73 & 120 & -24.61 & 188.84 & 120 & -21.41 & 182.09 \\
\hline & 4 & 120 & -20.29 & 85.23 & 150 & -16.74 & 82.51 & 120 & -25.74 & 220.13 & 120 & -22.39 & 212.43 \\
\hline & 5 & 120 & -21.10 & 103.20 & 150 & -17.19 & 100.16 & 150 & -27.44 & 237.07 & 150 & -23.87 & 227.94 \\
\hline \multirow{5}{*}{$\begin{array}{l}(4) \\
0.3\end{array}$} & 1 & 120 & -19.75 & 73.25 & 150 & -16.56 & 70.73 & 120 & -24.61 & 188.84 & 100 & -20.29 & 178.21 \\
\hline & 2 & 120 & -20.56 & 91.22 & 150 & -16.83 & 88.39 & 120 & -26.31 & 235.77 & 100 & -21.67 & 222.74 \\
\hline & 3 & 120 & -20.96 & 100.21 & 150 & -17.06 & 97.22 & 150 & -27.16 & 199.42 & 150 & -22.38 & 163.30 \\
\hline & 4 & 120 & -21.36 & 109.19 & 150 & -17.43 & 106.0 & 150 & -28.01 & 217.47 & 150 & -23.08 & 178.10 \\
\hline & 5 & 120 & -21.68 & 116.23 & 150 & -17.75 & 113.88 & 150 & -28.01 & 217.47 & 150 & -23.08 & 178.10 \\
\hline \multirow{5}{*}{$\begin{array}{l}(5) \\
0.4\end{array}$} & 1 & 120 & -21.13 & 103.87 & 150 & -17.21 & 100.82 & 150 & -26.91 & 200.78 & 150 & -22.26 & 163.80 \\
\hline & 2 & 120 & -21.90 & 121.17 & 150 & -17.91 & 117.82 & 150 & -28.43 & 234.53 & 150 & -23.54 & 191.50 \\
\hline & 3 & 120 & -21.90 & 121.17 & 150 & -17.91 & 117.82 & 150 & -28.43 & 234.53 & 150 & -23.54 & 191.50 \\
\hline & 4 & 120 & -22.44 & 133.15 & 150 & -18.39 & 129.59 & 150 & -29.50 & 238.81 & 150 & -24.42 & 210.60 \\
\hline & 5 & 120 & -22.42 & 132.63 & 150 & -18.42 & 130.1 & 120 & -27.75 & 219.23 & 150 & -23.26 & 185.70 \\
\hline
\end{tabular}


building is similar to 18 story building ranging from $19 \mathrm{~mm}$ to $30 \mathrm{~mm}$ with a maximum of $29.50 \mathrm{~mm}$ for (TB-S-30). This maximum displacement value also appeared under the earthquake zone 5 with a soil profile of 4 . It can be noticed that for both 18 and 30 story building, the vertical drift is comparatively more in the shell roof structure than the flat shaped ones and are within the permissible limits $(41.67 \mathrm{~mm})$.

For the horizontal displacement, it is observed that both shell and flat roof buildings give similar results in all the earthquake zones. The horizontal displacement values of 18 story-building increases with the increase in the earthquake zone 1 to 5 with the increase of soil profile 1 to 5 . The maximum horizontal displacement value for 18-story building occurs at the shell roof structure (TB-S-18) with a value of $133.15 \mathrm{~mm}$. For the 30 stories tube shaped building, the horizontal displacement exceeds the allowable deflection limit $(240 \mathrm{~mm})$ under the earthquake zones 4 and 5 and therefore the thickness of the slab increased from $120 \mathrm{~mm}$ to $150 \mathrm{~mm}$ accordingly to obtain the results within the allowable limits.

The Horizontal and vertical displacement for 18 and 30 stories tube-shaped building (Flat and Shell Roof) are displayed in Figure 7. The thickness for the shell roof of tube-shaped building remained constant $(120 \mathrm{~mm})$ for both 18 and 30 stories building whereas for flat roof building, it is $150 \mathrm{~mm}$ for 18 story and variation of $100 \mathrm{~mm}$ to $170 \mathrm{~mm}$ is observed for 30 story tube shaped building.

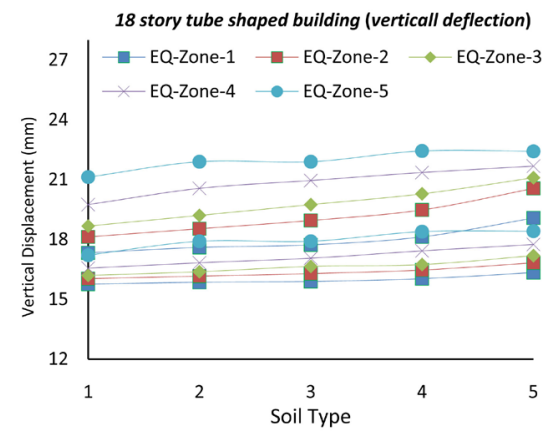

(a)

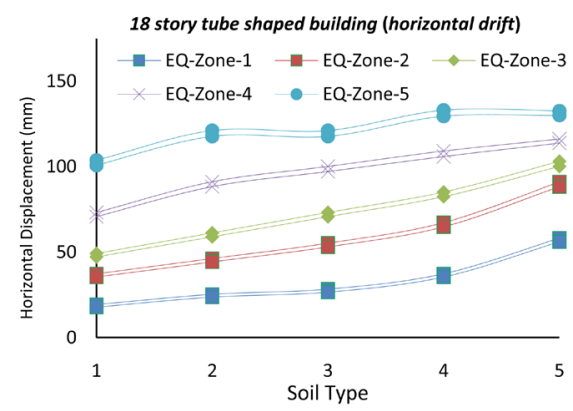

(c)

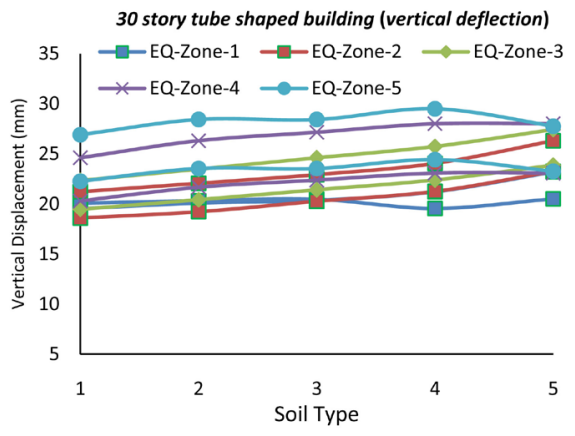

(b)

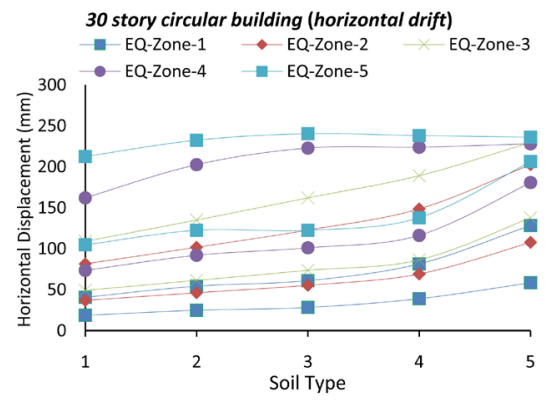

(d)

Figure 7. Vertical and horizontal displacement of tube-shaped building (30 and 18 stories). (a) Vertical displacement for 18 story tube shaped building; (b) Vertical displacement for 30 story tube shaped building; (c) Horizontal displacement for 18 story tube shaped building; (d) Horizontal displacement for 30 story tube shaped building. 


\section{Drift Index of Simulated Structural Models}

The drift indices for all the three studied structural models are displayed in Table 6 . The acceptable range for the drift index of conventional structures lies between the values of 0.002 and 0.005 (that is approximately $1 / 500$ to $1 / 200$ ). The drift index for all the buildings is close to $1 / 500$. Shell roof structure has drift index values less than $1 / 500$ for 30 stories building whereas the values are close to $1 / 500$ for 18 stories building. Moreover, the flat roof building, the drift index value is close to $1 / 500$ for 30 and 18 stories buildings.

\section{Results and Discussion}

The summary of horizontal and vertical displacements obtained for all the three simulated models (square, circular and tube-shaped building) are discussed in this section. The thicknesses for the shell and flat roof for all stimulated models are also compared. All the maximum horizontal and vertical deflections occur under the earthquake zone- 5 ( 0.40 gravitational acceleration) with soil profile- 5 (Soft soil), therefore a comparison is made between the slab/shell thickness with the horizontal displacement of each simulated building under earthquake zone-5. Figure 8 shows the relationship of slab/shell thickness to the horizontal displacement of square building.

It can be observed that shell thickness of square building $(120 \mathrm{~mm})$ for 18 story is less compared to flat roof building $(170 \mathrm{~mm})$. For thirty story building models, shell and flat roof building models have same slab/shell thickness but the horizontal displacement of shell roof has less value compared to the flat roof structure.

Table 6. Drift index results.

\begin{tabular}{ccccc}
\hline Sr. No & $\begin{array}{c}\text { Building } \\
\text { Code }\end{array}$ & $\begin{array}{c}\text { Max Horizontal } \\
\text { Displacement }\left(\Delta_{H(\max )}\right) /(\mathrm{mm})\end{array}$ & $\begin{array}{c}\text { Height of } \\
\text { Building }(H)(\mathrm{mm})\end{array}$ & $\begin{array}{c}\text { Drift Index } \\
\left(\Delta_{H(\max )}\right) / H\end{array}$ \\
\hline 1 & SRB-F-30 & 233.25 & 120,000 & 0.0019 \\
2 & SRB-S-30 & 176.62 & 120,000 & 0.0015 \\
3 & CB-F-30 & 288.65 & 120,000 & 0.0024 \\
4 & CB-S-30 & 206.53 & 120,000 & 0.0017 \\
5 & TB-F-30 & 316.03 & 120,000 & 0.0026 \\
6 & TB-S-30 & 335.27 & 120,000 & 0.0028 \\
7 & SRB-F-18 & 115.47 & 72,000 & 0.0016 \\
8 & SRB-S-18 & 135.50 & 72,000 & 0.0019 \\
9 & CB-F-18 & 114.63 & 72,000 & 0.0016 \\
10 & CB-S-18 & 135.72 & 72,000 & 0.0019 \\
11 & TB-F-18 & 130.10 & 72,000 & 0.0018 \\
12 & TB-S-18 & 132.63 & 72,000 & 0.0018 \\
\hline
\end{tabular}




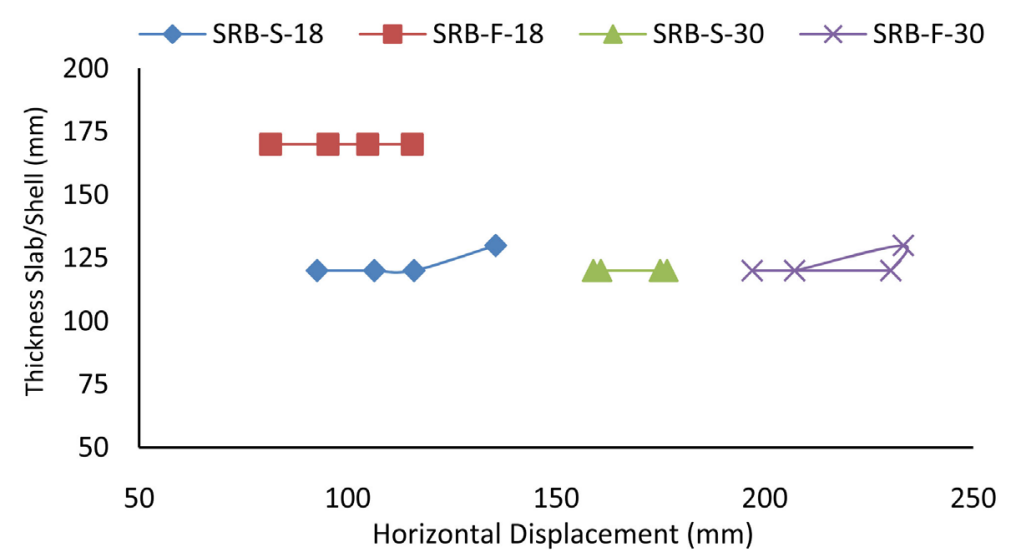

Figure 8. Slab thickness vs. horizontal displacement of square building.

Figure 9 displays the relationship of slab/shell thickness to the horizontal displacement of circular building. The shell thickness for both 18 and 30 story building is $120 \mathrm{~mm}$ which is less than the flat roof thickness $(150-170 \mathrm{~mm})$. The circular building with shell roof structure has less value of horizontal displacement compared to the flat roof structure. All the horizontal drift values obtained from both shell and flat roof are within the allowable limits of horizontal drift values.

The relationship of slab/shell thickness to the horizontal displacement of tube-shaped building is shown in Figure 10. Shell and flat roof structure have similar values of horizontal displacement but the thickness of shell roof (TB-S-18) is less $(120 \mathrm{~mm})$ as compared to the flat roof (TB-F-18) structure (150 $\mathrm{mm})$. Moreover, for the 30-story building both shell and flat roof has similar thickness with the horizontal displacement ranges from $160 \mathrm{~mm}$ to $240 \mathrm{~mm}$, which lies within the permissible limits.

Figure 11 shows the comparison results of maximum vertical displacements (Earthquake zone-5 with soil profile of 5) for 18 and 30 story simulated building models having flat and shell roof structure.

The vertical displacement for all the studied buildings is within the limit of maximum vertical displacement $\left(\Delta_{V(\max )}\right)$ i.e. $41.66 \mathrm{~mm}$. This maximum vertical displacement is shown as a reference line in red color in Figure 11. Both 18 and 30 stories buildings have similar range of vertical displacements, which is from $14 \mathrm{~mm}$ to $35 \mathrm{~mm}$. In addition, there is no specific difference in the vertical displacement of shell roof and flat roof shaped structure. Both types of roof structure lie within the same range of vertical displacement.

Figure 12 shows the comparison results of maximum horizontal displacements for 18 and 30 story simulated building models having flat and shell roof structure. The maximum horizontal displacement $\left(\Delta_{H(\max )}\right)$ allowed for 18-story building is $\left(\Delta_{H(\max )}=H / 500\right)=72,000 / 500=144 \mathrm{~mm}$ whereas for 30 stories, the maximum allowed horizontal displacement is $\left(\Delta_{H(\max )}=H / 500\right)=$ $120,000 / 500=240 \mathrm{~mm}$. Both of these allowable displacement limits are displayed as a reference line in red color. 


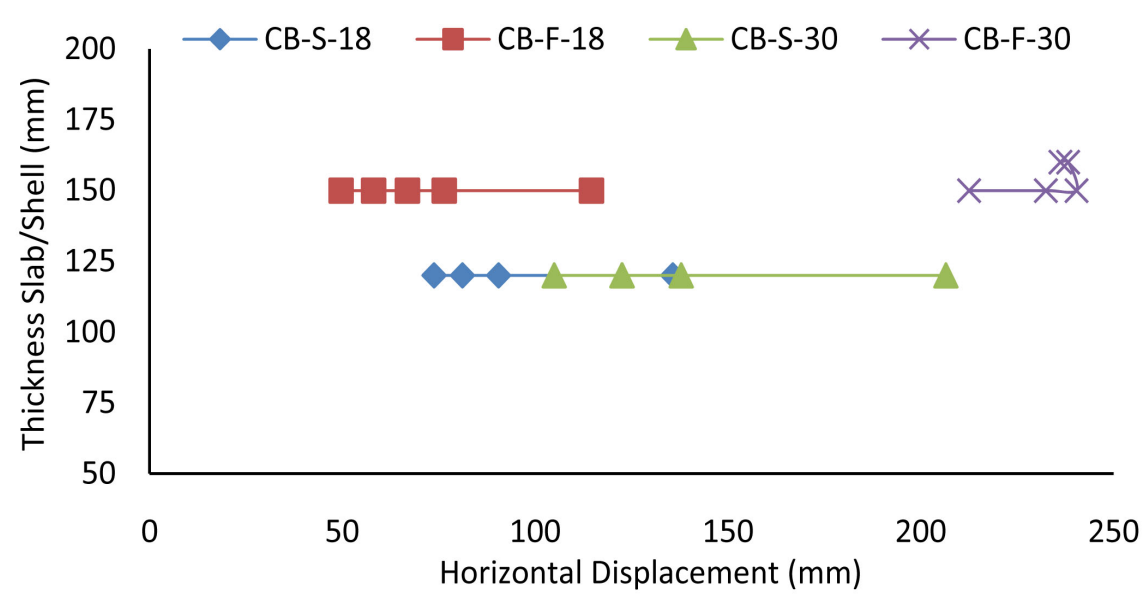

Figure 9. Slab thickness vs. horizontal displacement of circular building.

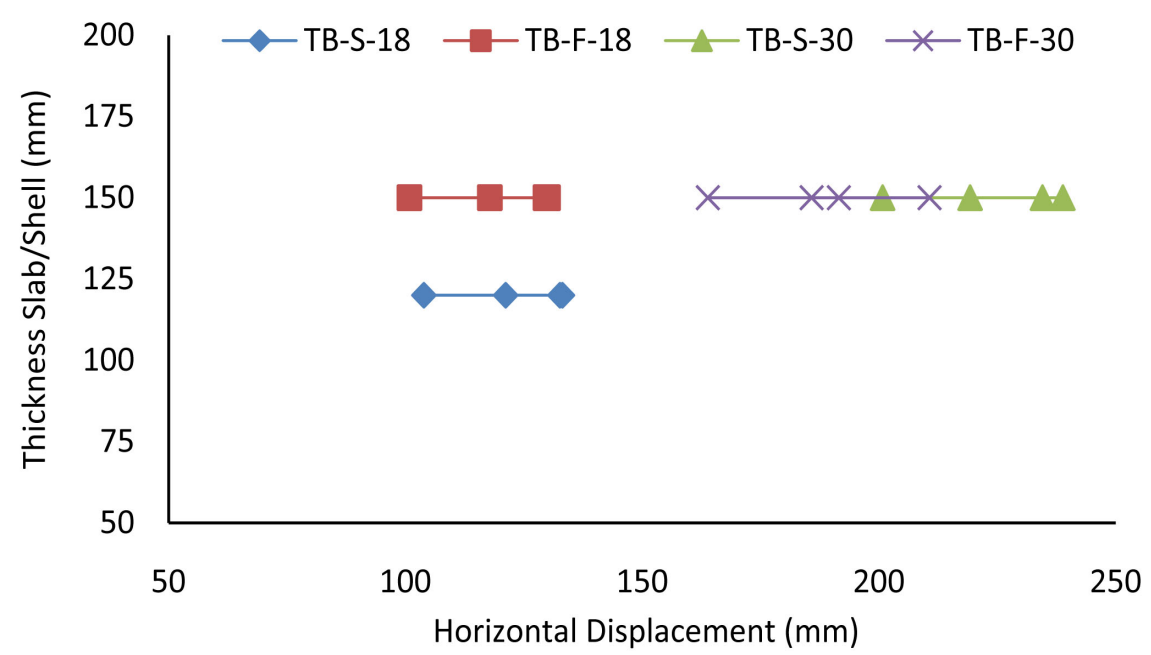

Figure 10. Slab thickness vs. horizontal displacement of tube-shaped building.

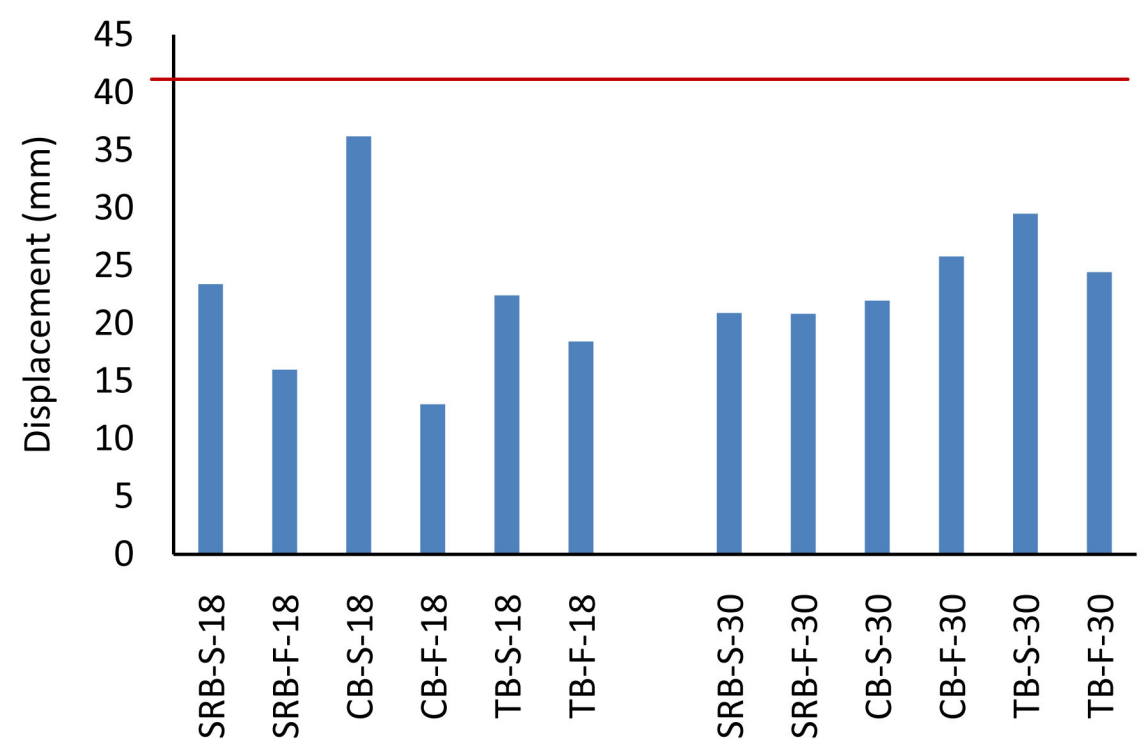

Figure 11. Vertical displacement of all simulated model buildings. 


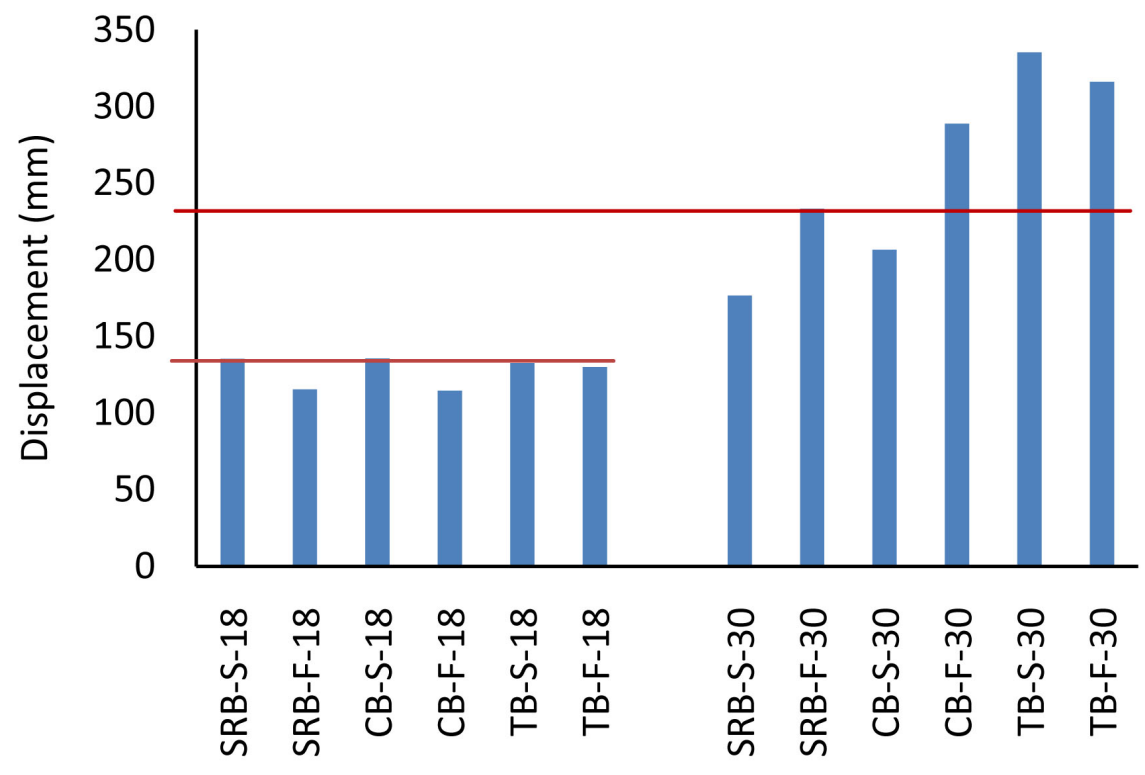

Figure 12. Horizontal displacement of all simulated model buildings.

\section{Conclusions}

This paper studies and analyzes tall buildings with shell and flat roof responses designed for gravity and seismic loads in different zones having different soil profiles. These tall buildings having two different heights and with different configurations are simulated with different load combinations. Five different earthquake zone factors (Z1 - Z5) along with the five different soil profiles (S1 - S5) are selected in this study.

The non-linear dynamic response of buildings was obtained using three simulated models of buildings; square, circular, and tube-shaped building with two different heights. Twelve building models, four under each category, are analyzed using the finite element software (STAAD pro) subjected to the gravity as well as earthquake loading defined by UBC and IBC codes. The responses of the simulated structural models with flat and shell roofs are studied and analyzed. These responses drew recommendations and guidelines for preliminary design of structurally efficient and reliable tall buildings with shell roof in earthquake zones.

Horizontal and vertical displacement comparison is made among the flat roof and shell roof building for 30 and 18 stories building satisfying the ACI code of design requirement and drift index of $1 / 500$ (0.002). The drift index value for all the simulated buildings is close to 0.002 . Shell roof structure has drift index values less than 0.002 for 30 stories building whereas the values are close to 0.002 for 18 stories building. Moreover, for the flat roof building, the drift index value is near to 0.002 for 30 as well as for 18 stories buildings.

All the maximum horizontal and vertical deflections occur under the earthquake zone-5 ( 0.40 gravitational acceleration) with soil profile-5 (Soft soil). The vertical displacements for shell and flat roof structures are close to each other for 18 and 30 story buildings. The horizontal displacement values obtained in all of 
three simulated models are within the allowable limits satisfying the ACI code of design requirement. For 18 story buildings, the horizontal displacements for square, circular and tube-shaped buildings are almost similar but the thickness of slabs having shell roof are lesser compared with the flat roof structure. Moreover, for 30-story building, the shell roof thickness has lower values compared to flat roof building. In addition, the horizontal deflection is lesser in the shell roof structure compared to the flat ones. Circular and square shaped building has the horizontal deflection within the allowable limits having lesser slab thickness compared to the flat shaped buildings. However, the tube-shaped building needs higher slab thickness to get the horizontal deflection within the permissible limits. The shell roof slab in all simulated models with less thickness than the flat roof slab did satisfy the horizontal and vertical deflection limits, therefore, it is more economical than the flat roof slab.

\section{Conflicts of Interest}

The authors declare no conflicts of interest regarding the publication of this paper.

\section{References}

[1] International Conference of Building Officials (1997) Uniform Building Code.

[2] International Code Council (2009) International Building Code.

[3] American Concrete Institute (2014) ACI Committee 318. Building Code Requirements for Structural Concrete (ACI 318-14): An ACI Standard: Commentary on Building Code Requirements for Structural Concrete (ACI 318R-14): An ACI Report.

[4] Khobragade, N.D. and Nikhade, A. (2016) Effects of Seismic Forces on Multi-Storey Building for Different Zones \& Soil Condition. International Journal for Technological Research in Engineering, 3, 2368-2371.

[5] Naidu, M. and Bhole, S.D. (2016). Seismic Analysis of Multi-Storied Building and Critical Study of Its Foundation. International Journal of Science Technology and Engineering, 2, 749-755.

[6] Imam, M.H. (2011) Influence of Structural and Soil Parameters on Mat Deflection. International Journal of Civil and Structural Engineering, 2, 1.

[7] Al-Ansari, M. and Senouci, A. (2011) Drift Optimization of High-Rise Buildings in Earthquake Zones. The Structural Design of Tall and Special Buildings, 20, 208-222. https://doi.org/10.1002/tal.530

[8] Al-Ansari, M.S. (2013) Reliability Index of Tall Buildings in Earthquake Zones. Open Journal of Earthquake Research, 2, 39. https://doi.org/10.4236/ojer.2013.23005

[9] Al-Ansari, M.S. (2011) Formulating Building: Response to Earthquake Loading. International Journal of Civil and Structural Engineering, 2, 305-317.

[10] McGraw-Hill Dictionary of Architecture and Construction. S.V. "Drift Index". https://encyclopedia2.thefreedictionary.com/drift+index

[11] Nowak, A.S. and Collins, K.R. (2012) Reliability of Structures. CRC Press, Boca Raton.

[12] Bowles, L.E. (1996) Foundation Analysis and Design. McGraw-Hill, New York. 